\title{
Product/service diversification through direct, indirect and additional services: librarian's perspective in Sri Lankan Universities
}

\section{J. J. Garusing Arachchige ${ }^{1}$}

In the prevailing competitive environment, libraries seem difficult to survive with traditional information services. Many of business organizations seem to practice multidimensional businesses and expand their profit potentials through diversification. Getting experience from business sector organizations, university libraries need to strategize the service delivery and retain the users through diversification of the product/service. Diversification can be implemented through innovation of directly related library services, indirectly related services and additional services probably not related to the typical library service but would be possible to provide by the library (out of the box). This paper investigates the Sri Lankan university librarians' perspective towards the implementation of such services in their libraries. The study also examines the possible barriers for the diversification. The paper involved the conceptual analysis and sample survey with library practitioners. Findings indicate that university libraries in Sri Lanka are providing diversity of services and have made many attempts to diversify them through 'direct library services', 'indirect library services' and 'additional services'. Relatively higher potential is shown with regard to directly and indirectly related services but the diversification through additional services indicated very low. The librarians face challenges for diversification stretching out through administrative factors, knowledge deficiencies, organizational environment and attitudinal issues of library managers.

Keywords: Product/service Diversification, Academic Libraries, University Library Diversification, Out of the Box Services, Information Marketing.

\footnotetext{
${ }^{1}$ Senior Assistant Librarian, Faculty of Engineering, University of Ruhuna, Email: jagathga@lib.ruh.ac.lk (iD https://orcid.org/0000-0002-2046-887X
} 


\section{Introduction}

Diversification is a marketing strategy utilized by business firms to achieve the growth of the business in terms of reaching new markets through developing or augmenting existing products or introducing new products. Product-service diversification concept has gained much attention after Igor Ansoff's (1957) introduction to conceptual model of Product-Market Growth Matrix. The theory explains of four types of growth potentials of a firm: Market Penetration, Product Development, Market Development and Diversification. The model concentrates on analyzing the situation to determine strategies for optimization of the profit and market share (Ansoff 2007). This approach aims to quantify internal information to match external operating environment of the firm (Moussetis, 2011). The diversification as a strategy is used by many profit sector businesses and evidences are found that the strategy has successfully applied to the non- profit sector too (Eckardt \& Skaggs, 2018). Organizations join with other business synergies (even with their competitors) and alter free community services a strategy to retain the market share (Eisenhardt, \& Galunic, 2000).

Diversification in the business sector implies pursuing of growth by providing completely new products or services to new markets. Diversification is a kind of risk related strategy because if practices it, the company needs to acquire new knowledge, new resources, new management, new technology and needs to deal with unfamiliar markets (Zhao \& Luo, 2002). Diversification can be basically strategized in two forms: concentric diversification (related diversification) and conglomerate diversification (unrelated diversification). Concentric or related diversification strategy is practiced when the company produces the products (core products) within the framework of company's existing scope. Unrelated (conglomerate) diversification occurs when a company steps into new businesses that are not related to existing core businesses (Ansoff 2007). Not only the business sector organizations, but also nonprofit organizations like media organizations, postal services, hospitals etc. are using product/service diversification strategy to retain their market share (Akingbola, Rogers \& Baluch, 2019). Experiences from such services are much important for academic libraries to prepare a service diversification models suitable to their institutions. 
In the socioeconomic environment dominated today, the information technology has created many changes in the library service. The library seems no longer able to play the 'first place role' to resort to information requirements of people. "The information world is very competitive. Librarians can no longer be 'arm - chair' library professionals encumbered with routine activities" (Iwu-James, Haliso, \& Ifijeh, 2019). One reason for this is that many non-library businesses have stepped in to the library's business territory. They seem to provide similar information services equally or better than libraries do. For a fact, there are many and variety of alternative information services (Kenney et al., 2003) manifested in forms of huge databases, smart search engines, digital content publishers and Open Access movements that provide scholarly and other information services for fee or free. This has narrowed the competitive edge of the library and as a result users' interest to the library seems to be declining (Iwu-James, Haliso, \& Ifijeh, 2019; Kenney et al., 2003; Tait, Konstantina, \& Peter 2016).

On the other hand, the constraints like budgetary restrictions and pressure from parent organizations insisting to prove the value of the library in the organizational context have provoked librarians to rethink of their current service models. Libraries need to adapt new strategies to win the competition and retain user-interest in order to exist as a valuable entity in the organization. It is discern that library's contribution to create social and intellectual values is still there, but it has been yet difficult to show the direct impact of the library on the economic factors of the society because existing mechanisms and models utilized to measure the impact of the library sector have so many limitations. Various attempts to show the Return On Investment (ROI) of the library have not been successful due to mechanism issues (Neal, 2011).

In this circumstance, libraries can incorporate or link with their similar service providers like mega databases, smart search engines and other information service movements to provide services in co-operate basis as a diversification strategy. Librarians can amalgamate their service models with other business models to address the different needs of users. Such strategies suggest that librarians should think of the diversified service models that users want today. 
Consuming pattern of the academic library market is quite different from other service businesses. It is highly specific to user segments. For a fact, undergraduates of a university require more general resources such as text books, journal articles specific to their own subject areas while teachers of the faculty require more research outputs and current research articles on the themes they are interested. On the other hand, undergraduates may require more study spaces in the library while teachers may need facility for online access at their home or office. Information needs can vary even within the segment. For instance, Arts students may need more borrowings for relaxed reading and medical students may need more opening hours of the library while engineering students need mobile access facilities to information whenever they require. Postgraduate students can be totally different from others and non-academic and administrative employees require different types of services from the library. Thus university libraries require diversification of services. It finds that the area related to Sri Lanka has not been covered by the empirical literature. Even theoretical conceptualization is very rare of the field.

\section{Research Objectives}

This article aims to conceptualize the potential of product/service diversification in academic libraries and explore how university librarians of Sri Lanka perceive the possibility of implementing the product/service diversification in their libraries. It also attempts to identify the barriers associated with the implementation of diversification. Based on the above purpose following specific objectives were formulated.

1. Explore the university librarians' perception towards implementation of product/service diversification in terms of directly related, indirectly related and additional service.

2. Identify the issues related to implementation of product/service diversification in university libraries in Sri Lankan context.

\section{Literature Review}

Generally, an organization operates in internal and external environments and the success of the business depends on how it manipulates the both internal and external environments. Organizations pay special attention to plan and revise their strategies frequently to fit the market demand as strategies are important to manipulate the service environment (Gluck, Kaufman, Walleck, 1980; Hitt, Ireland \& Hoskisson 2013). Internal environment of the firm 
represents the company's strength and capabilities while external environment represents the opportunities for the business and potentials of prospering. Internal environment of the firm includes its performances while external environment involves the benefits of these performances. Therefore organizations thrive to strategically balance these two environments through analyzing the external environment, assessing internal capabilities and then implementing strategies to adjust the external behavior of the firm (Tapera, 2014).

Strategic decisions can be aggressive and this aggressiveness should match the environmental turbulence (Ansoff, 2007). Environmental turbulence means the complexity, rapidity, and practicability of change. Aggressiveness of strategies refers to the novelty, discontinuity and speed of implementation of strategies. Capabilities mean the organization's characteristics which are supporting to respond to changes (Moussetis, 2011). Strategies appear as responses to company's capabilities and capabilities of a firm should support the strategies (Ansoff 2007). This provides the base for diversification.

As universities vary in their programmes, subject specialization and types of communities served, the services of the university library should be designed to cater the information needs of all categories. The services should be extended for other segments like alumni, members of other educational institutions and members of general or scholarly communities (Wilson, et al. 2019). Academic library's role in the $21^{\text {st }}$ century mainly focuses on providing space, information services, and tools to facilitate learning, creating conditions to support student success and persistence. The collaboration with stakeholders such as students, staff of the faculty, donors, well- wishers and architects (Kreitz, 2015 and Malenfant, 2011) is required. University libraries are expected to provide disciplinary work flows such as electronic laboratory note books, computational approach to textual analysis and support for traditional paper-based workflows. Academic librarian's service need to build up on network-based workflows of their users (Dempsey \& Malpas 2018).

Thus, the library service should be heterogeneous in the university, and this heterogeneity can be achieved through product/service development and diversification. Chad (2014) asserts that the diversification concept is adapted to library sector relatively later than other services. Moreover, in the rapid product obsolescence and market fragmentation environment, maximizing the fit between customer requirements and product characteristics is required (Schilling \& Hill 1998). Libraries need to be a partner in the creative process of learning and research rather than anchored to a collection. 
Theoretically diversification can be practiced vertically as well as horizontally (Ansoff 2007). Vertical diversification involves the modification or development of existing product /services in new forms and developing or repackaging of existing product/service to reach a target group. Horizontal diversification for example, means the use of existing strength of the library to provide complementary services for regular users. Launching of information literacy programmes, combination of cooperative library services linking with other libraries etc. are some examples in the academic library diversification (Walton, 2007). The library should observe new trends and should prove its unique role in the university frame (Trtikova \& Nemeckova, 2012).

Approach of diversification in the library service has a long history. Earlier libraries had only printed collections and now libraries have variety of resources including digital contents with various access means and formats. Same service can be repackaged for various groups such as elderly citizens. Library's physical space can be rearranged time to time and resource collections can be digitized to ease the use of them. Diversification in academic libraries can be practiced in various forms. For example, embodying of information literacy tutorials in the curriculum (Kerr, 2010; Quanlan \& Hegarty 2006), training via virtual library software, contributing to institutional record management process (Musembe, 2016), teaching in faculty curriculum, publishing support service for users, reference management citation support to users, dissemination of information via institutional digital repositories (Walton 2007), physical space planning (Ludwig \& Starr 2005; Williams \& Golden 2011), packaging of information for specific groups such as elderly users (Duizer, Robertson \& Han, 2009) etc. are practiced according to need of the community.

Shafique \& Riedling (2013) discuss of the application of Library 2.0 and Library 3D for the diversification of services. Library 2.0 is based on the Web 2.0 technologies. According to Boateng, Mbarika, \& Thomas (2010), Web 2.0 is a set of tools used for interactive communication using the Internet. For a fact, tools like blogs, wikis, Really Simple Syndication (RSS) feeds, list serves, Instant Messaging (IM) etc. are used today to share, exchange and publish information. This is an interactive tool where users can upload and download information. It has many social networking facilities (Kane, Robinson-Combre \& Berge, 2009). Gamage (2009) has emphasized the importance of applying Web 2.0 technology in library websites. Punchihewa (2018) found that adoption of Web 2.0 tools in university libraries is quite low. This has been asserted by Ranaweera and Li (2016). Library is not always a primary source for information (Curran et al. 2006) and the purpose of Library 2.0 is to facilitate people to use library services through the Internet 
and make them associate with the library interactively (Maness, 2006; Casy 2006; Casy \& Svastinuk 2007).

Web 2.0 features are the base of Library 3D (Rehman, \& Shafique, 2011). Through Library 3D, library patrons can involve in outreach services such as organizing of events (workshops, meetings, and exhibitions); conducting training programmes; collaborative and interactive discussion sessions; library training and many more that users required in the general life (Sauers \& Trueman, 2007). The use of 'Second Life' in the library has been highly elaborated by Hudson (2011). Information sharing tools (Flicker, YouTube, RSS feeds), social media networks (Facebook, MySpace, Linkedin), bookmarking (tagging), combining with virtual communities (Second Life) etc. can be used as transaction procedures for the library (Xu, Ouyang \& Chu, 2009). Gerolimos and Konsta (2011) assert that web services should be considered as the implementation of new technologies within a library's routine framework rather than a social element. Thus the literature above hints that a well extended ground for product/service diversification is available in university libraries.

Diversification of library service has many critiques too. Mainly there is a high risk of pitfall. It has strategic challenges because it can carry uncertainty of moving from current business to new business and sometimes with new resources (Lynch 2006). Librarians should make a good judgment of the diversification as libraries cannot thrive indefinitely in a single unchanging market. Unlike other organizations, the risk attached to diversification should be justified before implementing (Walton 2007). Specially unrelated diversification has a high risk of failings because lack of commonality or synergy in the market and stepping in to unfamiliar business cause many challenges. However diversification is essential in modern academic libraries for their existence. University libraries should thrive to diversification practices with related diversification as well as unrelated diversification.

\section{Methodology}

The study involved an instrument developed through theoretical conceptualization from literature review and sample survey with library professionals to empirically test the perception toward product/service diversification.

As attempts failed to find a well-defined and well tested instrument to measure the librarian's perception towards the product/service diversification in university libraries the author maintained an independent exploratory 
approach through literature review to prepare a fundamental scale. The author felt that it was difficult to perform a deep and micro level exploration in university libraries of Sri Lanka because the theme hasn't a mature ground in locality.

\section{Instrumentation}

Services offered by a library can vary depending on the type of the library, scope of the library, capacity and capabilities and users' requirements of the library. Even of university libraries, the service points and the nature of the service can vary based on the faculty type, subject streams, courses conducted and amount of funds available.

Firstly a literature review was conducted to identify the potential list of services that can be provided by a typical university library. Secondly the list was divided into three categories: directly related services, indirect services and additional services in academic library environment with the support of an expert group.

The author searched the PDQT Open (https://pqdtopen.proquest.com /search.html) 'university library services' and found 48748 open access dissertations and theses related to University library services. And the same search in Google Scholar found About 6,050,000 results. While browsing the search results the author found it is exhaustive and difficult to find a predetermined list of services. The search result found associated with much noise. Therefore, author resorted to randomly selected resources from above two searches and a number of globally renowned university library home pages and prepared a long list of services they provide. With professional experience, the author extracted 65 number of important service points applicable in Sri Lankan university library context. It is important to note that some general services such as newspaper reading facilities, access to past papers (which may be also provided by other services of the university) etc. were omitted on the author's perspective on the purpose of shortlisting. The list was sent to an expert panel of five library professionals and asked them to sort the items into three categories: directly related services, indirectly related services and additional services of academic libraries. The expert group consisted of five senior library professionals who hold professional qualifications such as MLS and PhD in Library and Information Science fields 
and had working experience more than 10 years in university libraries. Commonly expected services from any academic library such as lending of print materials, reference service, providing access to e-resources etc. were considered as directly related services. Services which are not compulsory, but can be provided by the library were considered as indirectly related. For a fact Lending of computers/laptops, Information Literacy courses for students, Entertainment facilities (Films, music, game etc.) by the library etc. were considered as indirectly related services. Other possible services such as 'doctors channeling', maintaining of tea/coffee/Nescafe /kiosks/ snack bars etc. attached to library and hall/auditorium lending service etc. that can be provided as additional services by the library for the purpose of cost recovery, profit earning or socialization of users were considered as additional services. The items in each category are as follows:

Directly related Service: Lending of print materials, Lending of e- materials (DVD/CD/Multimedia), Access facilities to ready reference sources (encyclopedia etc.), Reference Librarian's service, Access to full- text articles/e-books purchased by the library (offline), Access to Online Databases, Inter Library Loan services (print), Inter Library Loan services (digital), Access to OPAC, Comfortable study space in the library, Additional Reading Room facilities, Discussion Rooms for students, Space for serious studies (carrels), Maintain a Library Homepage, Active "Ask a Librarian" facility, Access to Tutorial collection (online), Library instructions for users, Information Desk for outside communities and Training / facilities for Open Access resources.

Indirectly related Service: Lending of computers/laptops, Lending of other materials (scanners, cameras, etc.), Research support services for researchers, Information Literacy training for users, Computer labs for students by the library, Gaming software installation in computers, Entertainment facilities (Films, music, game etc.) by the library, Information Literacy courses for students, Provision of Digital resources through Learning Management System (LMS), Links the library activities to Facebook, Links to library activities Twitter, Links to library activities Myspace, Links to other Social Media, Carrier Guidance programmes for outside users, Vocational Information for outside users, Exam support for school children, Maintaining 
information Web pages by the library, Weblogs by the library, Library portals, RSS (Really Simple Syndication) feeds, Seasonal celebrations by the library, Application of "Library 2.0), Application of "Library 3D" and Maintenance of Institutional Repositories (IR) by the library.

Additional Service: Community services such as Traveling information, occupational opportunities alert etc., Doctors channeling information, Maintenance of Wikis, Instance Message (IM) service, Flickr service, Application of Second Life (SL) tools, Provision of Cyberspace for users, Email clients service, Web browsers, RSS readers, Water filtering facilities in the library, Tea/coffee/Nescafe/Kiosks/ snack bars attached to library, Restaurant service attached to the library, Food stalls for users, Event organizing facilities by the library (conferences, seminars, workshop etc.), Accommodation (Keeping Guest houses) for users, Hall/Auditorium lending, Travel related services (ticket booking, tour organizing), Social welfare services, Kindergarten services by the library, Elder's homes by the library and Daycare Centers by the library.

It is worthy to note that expert panel had different opinions on categorization of some items. For a fact 2 members believed that maintaining information web pages by the library, Information Literacy courses for students and research support services should be included in the first category. However author took the liberty to put them into the second category considering the fact that categorization of services can vary depending on the current status of the library. It is also worthy to note that some services in the list can overlap, but the author decided to retain them in the purpose of obtaining responses in different directions.

The questionnaire was designed to check the perception of librarians towards the 65 items which represented 19 directly related services, 24 indirectly related services and 22 additional services. Respondents were asked to mark whether the statements (services) were 'already available', 'possible to implement', 'impossible to implement' or 'not idea of it'. Questionnaire also included 11 predetermined statements representing possible barriers for product/service diversification and respondents were asked to mark their opinion on options: 'totally agree', 'agree in some cases', 'no idea', 'disagree 
in some cases' or 'totally disagree' to the statements. Weightages for scales were allocated as 5, 4, 3, 2 and 1 respectively.

\section{Sampling and data collection}

A questionnaire based survey was administered in the study and the online questionnaire (Google Form) link was emailed in June 2019 to 98 university library professionals selected from ULA membership list of 2017 (Directory of Membership 2017, University Librarians Association of Sri Lanka).

The study sample was heterogeneous in educational level, designation, work experience, geographical location and subject major of their first degree studied. Respondents were from various subject disciplines such as Plant Biotechnology, Zoology, Chemistry, Library \& Information Science, Molecular Biology, Botany, Mathematics, Agricultural Science, Archaeology, Physics, Economics, Linguistics, Sociology, Sinhala language, Management, Psychology and Philosophy which showed a good blend of knowledge apart from the Library and Information Science.

\section{Results and Discussion}

51 responses out of 98 were received and the response rate was $52 \%$ which was a satisfactory amount for the study. Two (2) responses were discarded due to anomalies of responses and 49 responses were taken in to analysis. The respondents Sample included 7 Librarians, 29 Senior Assistant librarians, 1 Deputy Librarian and 12 Assistant Librarians. Among them there were $8 \mathrm{PhD}$ holders and 36 Masters Degree (MLS/MSc) holders and 5 BA/BSc holders. Respondents represented main libraries and faculty libraries. They were from different subject backgrounds. Thus the respondents can be considered come from heterogeneous sample population. This means that they would possess academic and managerial skills that can be positively used for the broad perspective of diversification potentials.

\section{Directly related services}

As identified above 19 service points represented 'directly related' library services. Table 1 shows the frequency of responses and the percentage of directly related services in terms of availability, possibility to implement, impossibility to implement and no idea of the matter. 
Table 01. Perception of availability, possibility, impossibility and no. idea position of 'directly related' services in university libraries.

\begin{tabular}{|c|c|c|c|c|c|c|c|c|}
\hline \multirow[b]{2}{*}{ Product/Service } & \multicolumn{2}{|c|}{$\begin{array}{c}\text { No. of } \\
\text { Available }\end{array}$} & \multicolumn{2}{|c|}{$\begin{array}{c}\text { No. of } \\
\text { Possible }\end{array}$} & \multicolumn{2}{|c|}{$\begin{array}{c}\text { No of } \\
\text { Impossible }\end{array}$} & \multicolumn{2}{|c|}{$\begin{array}{l}\text { No. of No } \\
\text { idea }\end{array}$} \\
\hline & Freq. & $\%$ & Freq. & $\%$ & Freq. & $\%$ & Freq. & $\%$ \\
\hline $\begin{array}{l}\text { Lending of print } \\
\text { materials }\end{array}$ & 49 & 100.0 & 0 & 0 & 0 & 0.0 & & 0.0 \\
\hline $\begin{array}{l}\text { Access facilities to } \\
\text { ready reference } \\
\text { sources } \\
\text { (encyclopedia etc.) }\end{array}$ & 47 & 95.9 & 2 & 4.1 & 0 & 0.0 & 0 & 0.0 \\
\hline $\begin{array}{l}\text { Access to Online } \\
\text { Databases }\end{array}$ & 46 & 93.9 & 1 & 2.0 & 2 & 4.1 & 0 & 0.0 \\
\hline $\begin{array}{l}\text { Library instructions } \\
\text { for users }\end{array}$ & 45 & 91.8 & 2 & 4.1 & 0 & 0.0 & 2 & 4.1 \\
\hline $\begin{array}{l}\text { Maintain a Library } \\
\text { Homepage }\end{array}$ & 44 & 89.8 & 3 & 6.1 & 0 & 0.0 & 2 & 4.1 \\
\hline Access to OPAC & 43 & 87.8 & 6 & 12.2 & 0 & 0.0 & 0 & 0.0 \\
\hline $\begin{array}{l}\text { Access to offline } \\
\text { full- text articles/e- } \\
\text { books purchased by } \\
\text { the library (Offline) }\end{array}$ & 40 & 81.6 & 6 & 12.2 & 3 & 6.1 & 0 & 0.0 \\
\hline $\begin{array}{l}\text { Inter Library Loan } \\
\text { services (print) }\end{array}$ & 40 & 81.6 & 9 & 18.4 & 0 & 0.0 & 0 & 0.0 \\
\hline $\begin{array}{l}\text { Reference } \\
\text { Librarian's service }\end{array}$ & 38 & 77.6 & 10 & 20.4 & 0 & 0.0 & 1 & 2.0 \\
\hline $\begin{array}{l}\text { Comfortable study } \\
\text { space in the library }\end{array}$ & 38 & 77.6 & 10 & 20.4 & 1 & 2.0 & 0 & 0.0 \\
\hline $\begin{array}{l}\text { Lending of e- } \\
\text { materials (DVD/CD/ } \\
\text { Multimedia) }\end{array}$ & 35 & 71.4 & 10 & 20.4 & 4 & 8.2 & 0 & 0.0 \\
\hline $\begin{array}{l}\text { Inter Library Loan } \\
\text { services (digital) }\end{array}$ & 34 & 69.4 & 12 & 24.5 & 2 & 4.1 & 1 & 2.0 \\
\hline $\begin{array}{l}\text { Training / facilities } \\
\text { for Open Access } \\
\text { resources }\end{array}$ & 34 & 69.4 & 11 & 22.4 & 2 & 4.1 & 2 & 4.1 \\
\hline $\begin{array}{l}\text { Additional Reading } \\
\text { Room facilities }\end{array}$ & 31 & 63.3 & 9 & 18.4 & 9 & 18.4 & 0 & 0.0 \\
\hline $\begin{array}{l}\text { Space for serious } \\
\text { studies (carrels) }\end{array}$ & 23 & 46.9 & 10 & 20.4 & 13 & 26.5 & 3 & 6.1 \\
\hline Active "Ask a & 20 & 40.8 & 23 & 46.9 & 1 & 2.0 & 5 & 10.2 \\
\hline
\end{tabular}




\begin{tabular}{|c|c|c|c|c|c|c|c|c|}
\hline \multicolumn{9}{|l|}{ Librarian" facility } \\
\hline $\begin{array}{l}\text { Discussion Rooms } \\
\text { for students }\end{array}$ & 19 & 38.8 & 16 & 32.7 & 12 & 24.5 & 2 & 4.1 \\
\hline $\begin{array}{l}\text { Information Desk for } \\
\text { outside communities }\end{array}$ & 19 & 38.8 & 23 & 46.9 & 5 & 10.2 & 2 & 4.1 \\
\hline $\begin{array}{l}\text { Access to Tutorial } \\
\text { collection (online) }\end{array}$ & 5 & 10.2 & 30 & 61.2 & 5 & 10.2 & 9 & 18.4 \\
\hline
\end{tabular}

According the table 1, highest availability occurred in lending of print materials $(100 \%)$. Access to ready references sources, online databases and OPAC etc. showed higher availability. Online access to Tutorial collection was the least available. However it has been marked as highest possible (61\%) to implement. In average, availability or possibility of implementing 'directly related' services were marked higher by respondents $(68 \%+22 \%=90 \%)$. Impossible to implement rate was very low $(7 \%)$. This indicates that directly related services have a high potential in diversification. However, $3 \%$ response on 'no idea' shows that some librarians are ambiguous in some services. Figure 01 shows this clearly.

\section{Indirectly Related Services}

Indirectly related services represented 24 items. According to the findings the most available indirectly related services were: Research support services for researchers (81.6\%), Information Literacy training for users $(73.5 \%)$, Maintenance of Institutional Repositories (IR) by the library (69.4\%), Computer lab facilities for students by the library (63.3\%) and Webpages by the library (59.2) respectively.

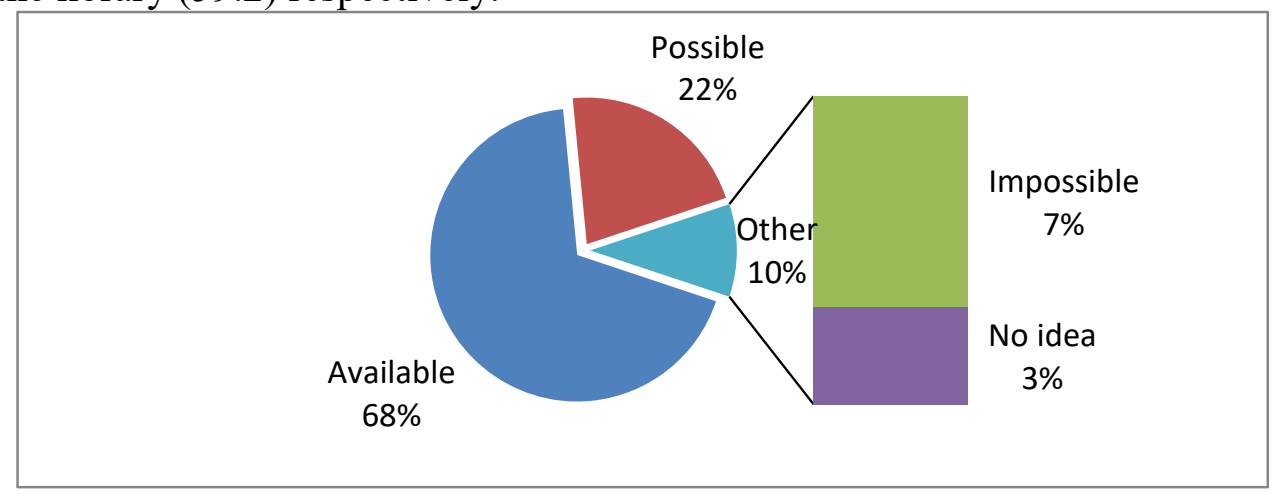

Figure 01. Percentage of Directly related library services in average of Availability, Possibility and Impossibility.

It is interesting that higher possibility of implementing is indicated in items such as Links to library activities Myspace (71\%), Links to other Social 
Media (69.4), Links to library activities Twitter (67.3), Provision of Digital resources through Learning Management System (55.1), Weblogs by the library (55.1) and Links the library activities to Facebook (53.1) most of which represented the Web 2.0 tools. The table 2 shows the ratings and percentage of each item in terms of availability, possibility to implement, impossibility implement and no idea of the matter.

Table 2. Frequency and percentage of Indirecly related services in terms of availability, possibility, impossibility and no idea.

\begin{tabular}{|c|c|c|c|c|c|c|c|c|}
\hline \multirow[b]{2}{*}{ Service Item } & \multicolumn{2}{|c|}{$\begin{array}{c}\text { No. of } \\
\text { Available }\end{array}$} & \multicolumn{2}{|c|}{$\begin{array}{c}\text { No. of } \\
\text { Possible }\end{array}$} & \multicolumn{2}{|c|}{$\begin{array}{c}\text { No of } \\
\text { Impossible }\end{array}$} & \multicolumn{2}{|c|}{$\begin{array}{l}\text { No. of No } \\
\text { idea }\end{array}$} \\
\hline & Freq. & $\%$ & Freq. & $\%$ & Freq. & $\%$ & Freq. & $\%$ \\
\hline $\begin{array}{l}\text { Links to library } \\
\text { activities } \\
\text { Myspace }\end{array}$ & 2 & 4.1 & 35 & 71.4 & 3 & 6.1 & 9 & 18.4 \\
\hline $\begin{array}{l}\text { Links to other } \\
\text { Social Media }\end{array}$ & 7 & 14.3 & 34 & 69.4 & 4 & 8.2 & 4 & 8.2 \\
\hline $\begin{array}{l}\text { Links to library } \\
\text { activities } \\
\text { Twitter }\end{array}$ & 4 & 8.2 & 33 & 67.3 & 3 & 6.1 & 9 & 18.4 \\
\hline $\begin{array}{l}\text { Provision of } \\
\text { Digital } \\
\text { resources } \\
\text { through } \\
\text { Learning } \\
\text { Management } \\
\text { System (LMS) }\end{array}$ & 13 & 26.5 & 27 & 55.1 & 4 & 8.2 & 5 & 10.2 \\
\hline $\begin{array}{l}\text { Weblogs by the } \\
\text { library }\end{array}$ & 7 & 14.3 & 27 & 55.1 & 4 & 8.2 & 11 & 22.4 \\
\hline $\begin{array}{l}\text { Links the library } \\
\text { activities to } \\
\text { Facebook }\end{array}$ & 16 & 32.7 & 26 & 53.1 & 3 & 6.1 & 4 & 8.2 \\
\hline $\begin{array}{l}\text { Information } \\
\text { Literacy courses } \\
\text { for students }\end{array}$ & 20 & 40.8 & 23 & 46.9 & 3 & 6.1 & 3 & 6.1 \\
\hline Library portals & 10 & 20.4 & 23 & 46.9 & 6 & 12.2 & 9 & 18.4 \\
\hline $\begin{array}{l}\text { Carrier } \\
\text { Guidance } \\
\text { programmes for } \\
\text { outside users }\end{array}$ & 8 & 16.3 & 23 & 46.9 & 9 & 18.4 & 9 & 18.4 \\
\hline
\end{tabular}




\begin{tabular}{|c|c|c|c|c|c|c|c|c|}
\hline $\begin{array}{l}\text { RSS (Really } \\
\text { Simple } \\
\text { Syndication) } \\
\text { feeds }\end{array}$ & 7 & 14.3 & 23 & 46.9 & 5 & 10.2 & 14 & 28.6 \\
\hline $\begin{array}{l}\text { Application of } \\
\text { "Library 2.0) }\end{array}$ & 7 & 14.3 & 21 & 42.9 & 4 & 8.2 & 17 & 34.7 \\
\hline $\begin{array}{l}\text { Vocational } \\
\text { Information for } \\
\text { outside users }\end{array}$ & 6 & 12.2 & 21 & 42.9 & 8 & 16.3 & 14 & 28.6 \\
\hline $\begin{array}{l}\text { Exam support } \\
\text { for school } \\
\text { children }\end{array}$ & 3 & 6.1 & 20 & 40.8 & 15 & 30.6 & 11 & 22.4 \\
\hline $\begin{array}{l}\text { Application of } \\
\text { "Library 3D" }\end{array}$ & 3 & 6.1 & 18 & 36.7 & 6 & 12.2 & 22 & 44.9 \\
\hline $\begin{array}{l}\text { Maintaining } \\
\text { information } \\
\text { Web pages by } \\
\text { the library }\end{array}$ & 29 & 59.2 & 17 & 34.7 & 2 & 4.1 & 1 & 2.0 \\
\hline $\begin{array}{l}\text { Seasonal } \\
\text { celebrations by } \\
\text { the library }\end{array}$ & 18 & 36.7 & 17 & 34.7 & 9 & 18.4 & 5 & 10.2 \\
\hline $\begin{array}{l}\text { Entertainment } \\
\text { facilities (Films, } \\
\text { music, game } \\
\text { etc.) by the } \\
\text { library }\end{array}$ & 9 & 18.4 & 14 & 28.6 & 19 & 38.8 & 7 & 14.3 \\
\hline $\begin{array}{l}\text { Information } \\
\text { Literacy } \\
\text { training for } \\
\text { users }\end{array}$ & 36 & 73.5 & 13 & 26.5 & & 0.0 & 0 & 0.0 \\
\hline $\begin{array}{l}\text { Gaming } \\
\text { software } \\
\text { installed in } \\
\text { computers }\end{array}$ & 0 & 0.0 & 12 & 24.5 & 30 & 61.2 & 7 & 14.3 \\
\hline $\begin{array}{l}\text { Lending of } \\
\text { computers/lapto } \\
\text { ps }\end{array}$ & 8 & 45.8 & 11 & 22.4 & 25 & 51.0 & 5 & 10.2 \\
\hline $\begin{array}{l}\text { Computer labs } \\
\text { for students by } \\
\text { the library }\end{array}$ & 31 & 63.3 & 10 & 20.4 & 8 & 16.3 & 0 & 0.0 \\
\hline $\begin{array}{l}\text { Lending of } \\
\text { other materials }\end{array}$ & 6 & 12.2 & 10 & 20.4 & 24 & 49.0 & 9 & 18.4 \\
\hline
\end{tabular}




\begin{tabular}{lllllllll}
\hline $\begin{array}{l}\text { (scanners, } \\
\text { cameras, etc.) }\end{array}$ & & & & & & & & \\
$\begin{array}{l}\text { Maintenance of } \\
\begin{array}{l}\text { Institutional } \\
\text { Repositories } \\
\text { (IR) by the }\end{array}\end{array}$ & 34 & 69.4 & 8 & 16.3 & 3 & 6.1 & 4 & 8.2 \\
$\begin{array}{l}\text { library } \\
\begin{array}{l}\text { Research } \\
\text { support services } \\
\text { for researchers }\end{array}\end{array}$ & 40 & 81.6 & 7 & 14.3 & 2 & 4.1 & 0 & 0.0 \\
\hline
\end{tabular}

When considered in average, 'indirectly related' services are already available in $27 \%$ of libraries and are possible to implement in $39 \%$ libraries. $17 \%$ of respondents indicated that it is impossible to implement and similarly $17 \%$ of respondents had no idea of these services. The statistics indicate that indirectly related services are available or possible to implement in $66 \%$ libraries $(39+27)$. This is a positive approach of librarians towards diversification, but a considerable amount of libraries cannot implement them because $34 \%$ of respondents have indicated that the services are impossible to implement or no idea of the matter (figure 2).

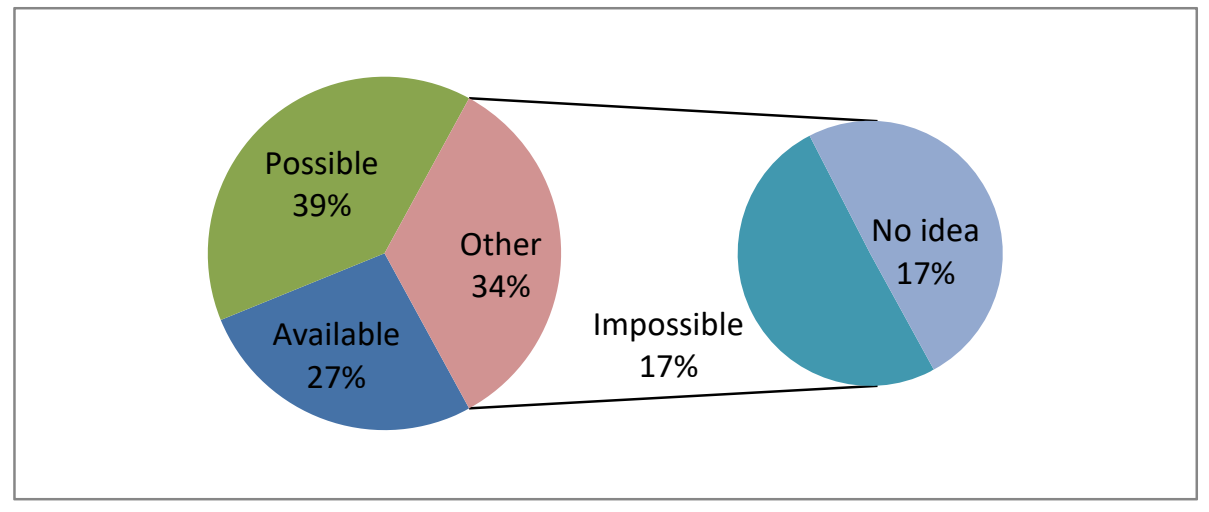

Figure 2. Percentages of Availability, Possibility and Impossibility of Indirectly related library services in average

\section{Additional Services}

22 additional services were tested in the study. With regard to additional services, most available services were E-mail clients (67.3\%) and Event organizing facilities by the library (51\%). Instance Message (IM) service (59.2), Maintenance of Wikis (57.1) and Provision of Cyberspace for users 
(49\%) indicated most possible relatively. A higher number of respondents had No Idea regarding Web browsers (100\%), RSS readers (100\%), and Application of Second Life (SL) tools (57.1\%). Relatively choice of a higher number of respondents' was 'impossible to implement' regarding the Daycare Centers by the library (65.3\%), Elder's homes by the library (65.3\%), Restaurant service attached to the library (61.2), Food stalls for users (57.1), Kindergarten services by the library (57.1) and Travel related services (ticket booking, tour organizing (51.0). These findings indicate that librarians are reluctant to step in to multi-business models that are foreign to library service territory. Table 3 shows in detail how respondents have perceived the selected additional services in terms of availability, possibility to implement, impossibility to implement and no idea of the matter.

Table 3 - Frequency and percentage of Additional services in terms of availability, possibility, impossibility and no idea

\begin{tabular}{|c|c|c|c|c|c|c|c|c|}
\hline \multirow[t]{2}{*}{ Service Item } & \multicolumn{2}{|c|}{ Available } & \multicolumn{2}{|c|}{ Possible } & \multicolumn{2}{|c|}{ Impossible } & \multicolumn{2}{|c|}{ No idea } \\
\hline & Frq. & $\%$ & Frq. & $\%$ & Frq. & $\%$ & Frq. & $\%$ \\
\hline $\begin{array}{l}\text { Daycare Centers by the } \\
\text { library }\end{array}$ & 0 & 0.0 & 4 & 8.2 & 32 & 65.3 & 13 & 26.5 \\
\hline $\begin{array}{l}\text { Elder's homes by the } \\
\text { library }\end{array}$ & 0 & 0.0 & 1 & 2.0 & 32 & 65.3 & 16 & 32.7 \\
\hline $\begin{array}{l}\text { Restaurant service } \\
\text { attached to the library }\end{array}$ & 0 & 0.0 & 12 & 24.5 & 30 & 61.2 & 7 & 14.3 \\
\hline Food stalls for users & 0 & 0.0 & 14 & 28.6 & 28 & 57.1 & 7 & 14.3 \\
\hline $\begin{array}{l}\text { Kindergarten services by } \\
\text { the library }\end{array}$ & 0 & 0.0 & 5 & 10.2 & 28 & 57.1 & 16 & 32.7 \\
\hline $\begin{array}{l}\text { Travel related services } \\
\text { (ticket booking, tour } \\
\text { organizing) }\end{array}$ & 0 & 0.0 & 6 & 12.2 & 25 & 51.0 & 18 & 36.7 \\
\hline $\begin{array}{l}\text { Accommodation } \\
\text { (Keeping Guest houses) } \\
\text { for users }\end{array}$ & 4 & 8.2 & 8 & 16.3 & 24 & 49.0 & 13 & 26.5 \\
\hline Hall/Auditorium lending & 17 & 34.7 & 8 & 16.3 & 23 & 46.9 & 1 & 2.0 \\
\hline $\begin{array}{l}\text { Tea/coffee/Nescafe/Kios } \\
\mathrm{ks} / \text { snack bars attached } \\
\text { to library }\end{array}$ & 8 & 16.3 & 18 & 36.7 & 17 & 34.7 & 6 & 12.2 \\
\hline Social welfare services & 13 & 26.5 & 13 & 26.5 & 15 & 30.6 & 8 & 16.3 \\
\hline $\begin{array}{l}\text { Doctors channeling } \\
\text { information }\end{array}$ & 3 & 6.1 & 13 & 26.5 & 14 & 28.6 & 19 & 38.8 \\
\hline
\end{tabular}




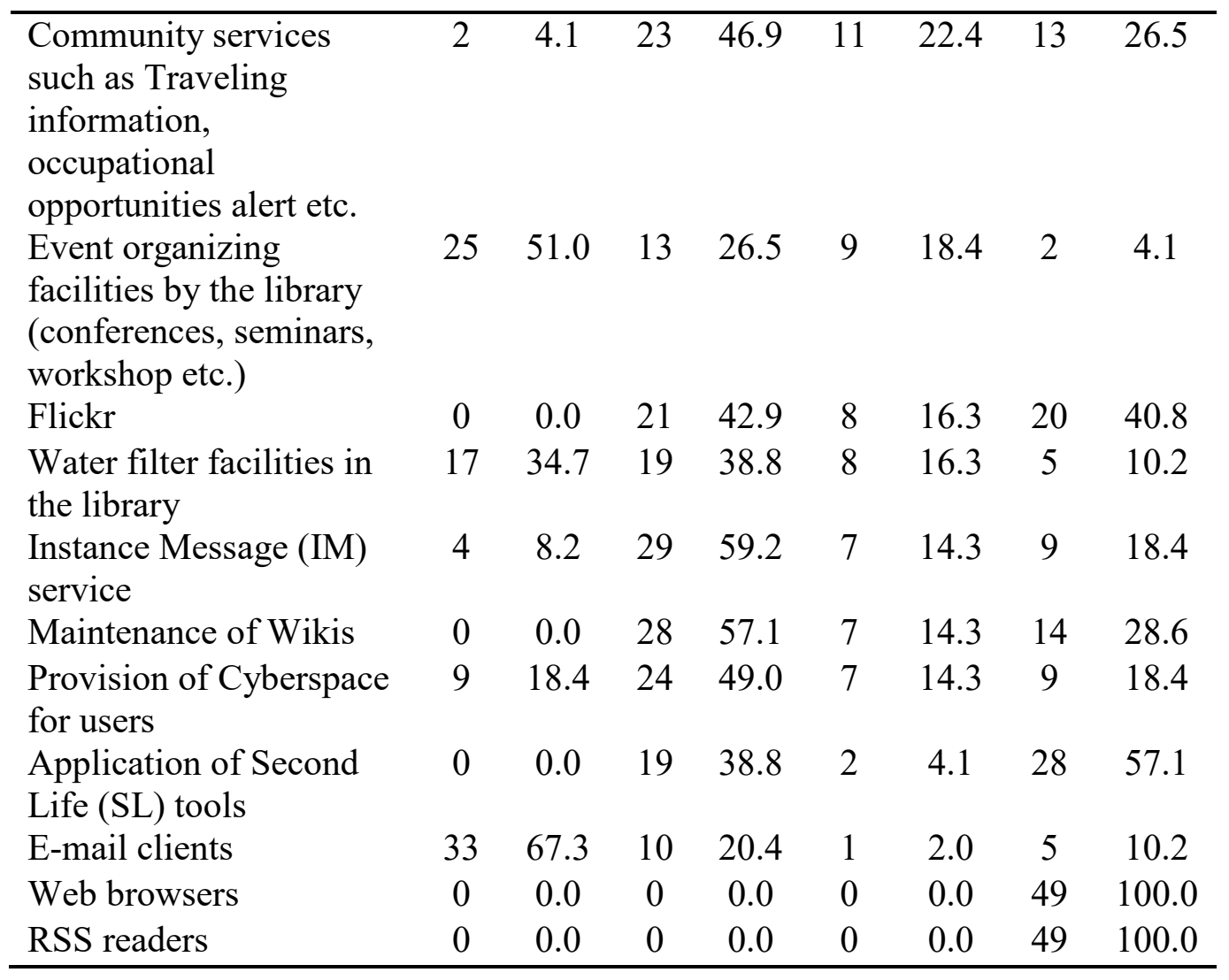

The results indicate that libraries have tried to provide additional services in the library. It also finds that respondents have perception difficulties of economic approaches of the library. The higher rate on 'No Idea' option is evident for this interpretation.

However, it also showed positive approach too that some respondents had identified a number of additional services as possible to implement in their libraries. Additional services were the least available in all libraries and less possible to implement compared to other services. Figure 3 gives a clear picture regarding the perception of the additional services in average.

According to figure 3 , in average a low percentage (13\%) of libraries already maintain additional services. $27 \%$ of library professionals perceived the additional services as possible in their libraries. $30 \%$ of respondents rated them as impossible and a similar percentage had 'No idea' it. If we consider 
availability + possibility as positive and the rest as negative perception, we find that majority of respondents are on negative side $(60 \%)$.

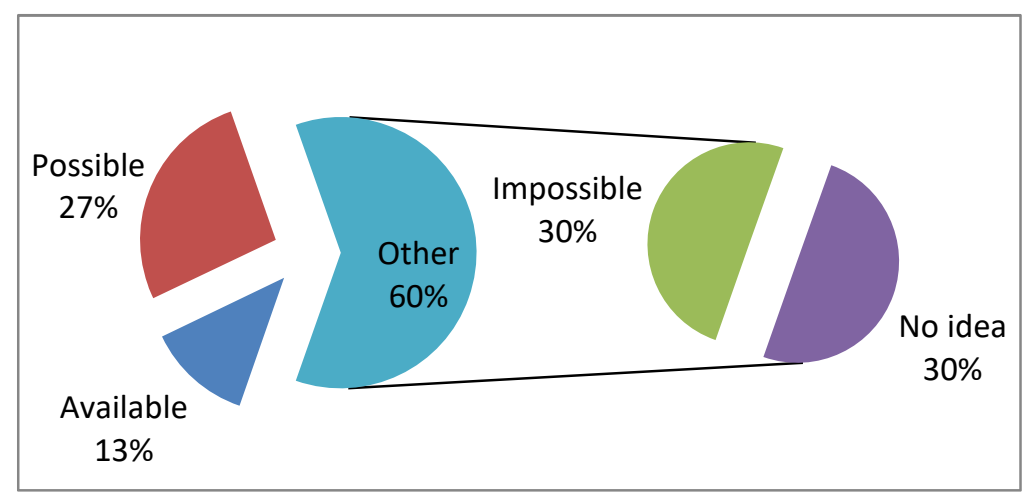

\section{Figure 03. Percentage of additional services in average of Availability, Possibility, Impossibility and no idea.}

The possibility and impossibility of implementing additional services are critical because libraries have to take the risk of stepping into other businesses which are not familiar to the library service. Statistics indicate that possibility $(27 \%+13 \%=40 \%)$ is less than impossibility $(30 \%+30 \%=60 \%)$. The option 'No idea' is considered as favored over impossible in this case.

In comparison of all three service categories (figure 4), it is discern that directly related services are highly available in university libraries (Mean = 34.2). Indirectly related services are less available (Mean $=13.5)$ but they are quite possible to implement (Mean $=19.7)$. This means that university libraries are well in a position to consider service diversification through indirectly related services compared to other two categories. However, additional services are the least available (Mean $=6.4$ ) and less possible (Mean 13.7) in the library. A considerable amount of respondents believe that additional services are impossible (Mean 14.9) or don't have idea of them (Mean 15.6).

\section{Issues for Product diversification}

The study attempted to explore the issues and barriers cause to implement the product/service diversification practices in university libraries. The probable issues and barriers were conceptualized through literature review and author's working experience in the library.

Eleven (11) factors were identified as barriers for implementing product / service diversification in academic libraries viz. Lack of necessary resources, (LackResources); lack of enough knowledge of the staff (NoStafKnowledge); 
no capacity or capabilities in the library (NoCapabilities); no sufficient authority/power transferred to take relevant decisions (NoPower); no interest from stake holders on diversification (NoUser Interest); no customer base or competitive demand for such services (NoCompetion); external barriers like political, cultural and legal (ExtBariors); the library concentrates only on related service (NoConcentr); lack of enough time for such services (NoTime); lack of sufficient cooperation from the staff (NoStaCor) and institutional regulations are not flexible (NoFlexRegu) for such services.

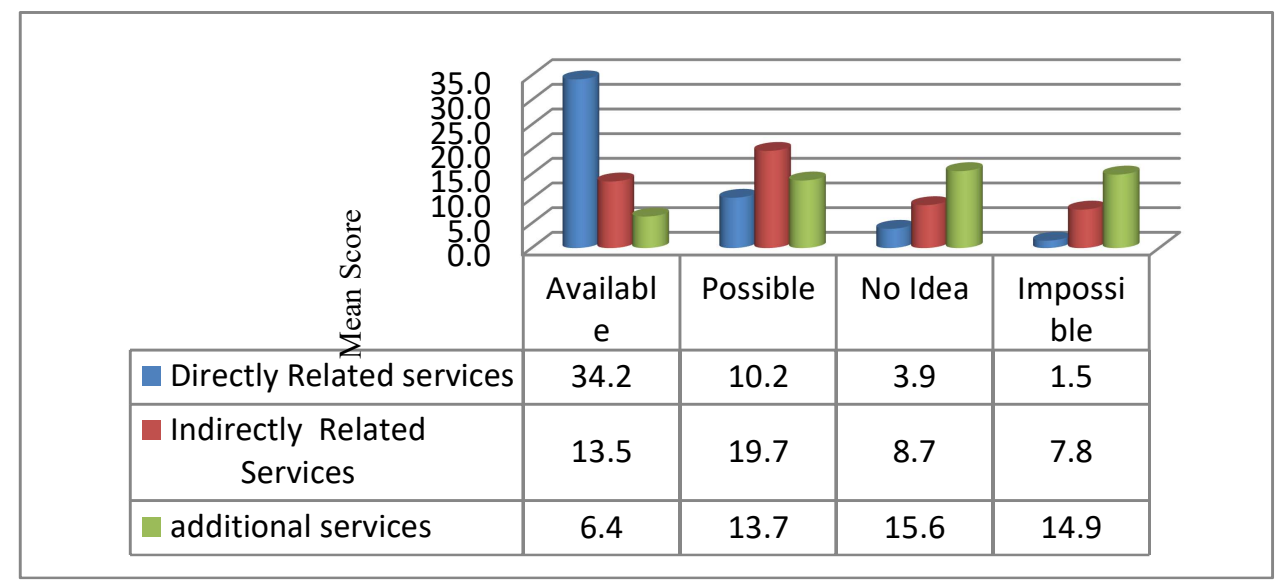

Figure 4. Mean score of directly related, indirectly related and additional services in terms of availability, possibility, impossibility and no idea

All the responses were calculated according to the allocated weight for each scale. When mean score of weighted total is considered, the items (issues) from most influential to least influential is as follows: Lack of sufficient resources for the library (Mean 3.53), Librarians concentrate only on purely library related services (Mean 3.29), Non-flexibility of parent organization's regulations to implement such services (Mean 3.29), Unavailability of time to provide such services apart from regular services (Mean 3.17), No sufficient power or authority to take such decisions (Mean 3.16), No demand or user interest for these services (Mean 3.12), No competitive base for such services (Mean 3.06), Lack of sufficient cooperation from the staff (Mean 2.9), Insufficient expert knowledge of the staff (Mean 2.86), External barriers such as political, cultural or legal issues (Mean 2.84) and Insufficient capacity or capabilities of the library (Mean 2.8).

When considered the Standard Deviation of responses, the order comes as Lack of sufficient resources for the library, Insufficient expert knowledge of the staff, Insufficient capacity or capabilities of the library, No sufficient 
power or authority to take such decisions, No demand or user interest for these services, No competitive base for such services, External barriers such as political, cultural or legal issues, Librarians concentrate only on purely library related services, Unavailability of time to provide such services apart from regular services, Lack of sufficient cooperation from the staff, Non-flexible regulations of parent organizations to implement such services.

The results indicate that university libraries have various difficulties when they implement diversification in products/services. These difficulties stretch out through administrative factors, knowledge deficiencies, organizational environment and attitudinal issues of library administrators.

\section{Conclusions}

The article concentrated on two objectives. Explore librarians' perception towards the product/service diversification and to identify the issues related to implementation of product/service diversification in university libraries of Sri Lanka.

The study found that university libraries in Sri Lanka have mostly approached the 'Directly Related' service diversification strategy through renovating and enhancing core services which are expected from a general academic library. However many librarians have perceived the ability to implement 'Indirectly related service diversification' through a number of extension services attached to the library. For a fact, librarians have attempted to practice Research Support services, Information Literacy training for users, Maintenance of Institutional Repositories (IR), Computer lab service, Maintaining of information Web pages and incorporating Information Literacy with teaching modules. The fact that a higher number of library professionals had 'No idea' regarding the 'additional services' may imply that additional services are unrelated to the university library. Moreover, many of librarians seemed to view that as impossible and taking an unnecessary risk.

\section{Recommendations}

This scenario implies that the roles of academic libraries are changing with the change of users' expectations. Users seek for the diversity of services offered by the academic library and they fulfill their information requirements from a variety of service providers other than the library. To survive in the competitive environment, libraries need to practice product / service diversification as a strategy.

Diversification can appear as 'Directly related diversification', 'Indirectly related diversification' and 'Additional diversification' in the academic library context. The categorization of services can have differences based on the 
library's status, availability of resources and users' requirements because the core level of services is determined based on them.

Diversification is difficult in academic libraries due to many issues. These issues can be mainly associated with administrative factors, knowledge deficiencies, organizational environment and attitudinal issues of library administrators. Therefore librarians may concentrate on overcoming the investment issues, manpower training, and managing market environment of the library.

Library service in nature is flexible to adapt the related services as well as additional services. Sri Lankan university libraries have concentrated on diversification through related service (direct or indirect) but there are opportunities for practicing additional services that can be directed for revenue earning. Academic libraries can diversify their services with the use of new technology, web resources and simple revenue earning mechanisms such as renting auditorium, organizing venue for events and space planning for social activities etc. This study uncovers a wide area of further research in the field. It is encouraged to explore the library's relationship with entrepreneurship, digital marketing and social media application. Future research may replicate the study with new instrument and broader spectrum of respondents.

\section{References}

Akingbola, K., Rogers, S. E. \& Baluch, A. (2019). Change management in nonprofit organizations: theory and Practice. Palgrave Macmillan/Springer: Gewerbestresse.

Ansoff, H. I. (2007). Strategic Management [Classic ed.]. Palgrave Macmillan : Houndmills.

Ansoff, I. (1957). Strategies for diversification. Harvard Business Review, 35(5), 113-124.

Boateng, R., Mbarika, V., \& Thomas, C. (2010). When Web 2.0 becomes an organizational learning tool: evaluating Web 2.0 tools. Development and Learning in Organizations, 24(3), 17-20.

Casey, M. (2006). Library Crunch: bringing you a library 2.0 perspective. Available at http://www.librarycrunch.com/ [Accessed May 18, 2006]. 
Casey, M. E. \& Laura C. Savastinuk. L.C. (2007). Library 2.0: a guide to participatory library service. Medford, N.J.: Information Today.

Chad, K. (2014). Library management system to library services platform. Resource management for libraries: a new perspective Ken Chad. HELibTech Briefing Paper. August 2015 Technical Report - [online] DOI: 10.13140/ RG.2.1.4315.3128.

Curran, K., Murray, M., Norrby, D. S. \& Christian, M. (2006), Involving the user through Library 2.0. New Review of Information Networking, 12(1), 4759.

Dempsey L. \& Malpas C. (2018). Academic library futures in a diversified university system. In: Gleason N. (eds) Higher education in the era of the Fourth Industrial Revolution. 65-89. Palgrave Macmillan :Singapore.

Duizer, L. M., Robertson, T., \& Han, J. (2009). Requirements for packaging from an ageing consumer's perspective. Packaging Technology and Science, 22(4), 187-197. doi:10.1002/pts.834.

Eckardt, R., \& Skaggs, B. C. (2018). Service diversification and growth of professional service firms. Long Range Planning, 51(1), 111-126. doi:10. 1016/j.lrp.2017.06.003

Eisenhardt, K. M., \& Galunic, D. C. (2000). Coevolving at last, a way to make synergies work. Harvard Business Review, 78(1), 91.

Gamage, R. (2009). Extended roles and responsibilities of library sssociation web sites. Journal of the University Librarians Association of Sri Lanka, 13(1), 47-60. https://doi.org/10.4038/jula.v13i1.1333.

Gerolimos, M. \& Konsta, R. (2011). Services for academic libraries in the new era. D-Lib Magazine, 17(7/8), 1-22.

Gluck, F.W., Kaufman, S.P. \& Walleck, A.S. (1980). Strategic management for competitive advantage. Harvard Business Review. 58(4), 154-161.

Hitt, M. A., Ireland, R.D. \& Hoskisson, R.E. (2013). Strategic management: concepts and cases: competitiveness and globalization. South-Western Cengage Learning:Australia. 
Hudson, A. (2011). Librarians in Second Life and future Virtual Worlds. In: Zabel, D., ed. 2011. Reference Reborn: Breathing New Life into public services librarianship. California:ABC-CLIO, LCC. Ch. 5.

Iwu-James, J., Haliso, Y., \& Ifijeh, G. (2019). Leveraging competitive intelligence for successful marketing of academic library services. New Review of Academic Librarianship, 26(1) 151-164. doi:10.1080/1361 4533.2019.1632215.

Kane K, Robinson-Combre J \& Berge Z. L. (2009). Tapping into social networking: collaborating enhances both knowledge management and elearning. The Journal of Information and Knowledge Management Systems, 40(1), 62-70.

Kenney, A. K., McGovern, N. Y., Martinez, I. T., \& Heidig, L. T. (2003). Google meets eBay: what academic librarians can learn for alternative information providers. D-Lib Magazine, 9(6), Retrieved from http://www.dlib.org/dlib/june03/kenney/06kenney.html [accessed March 30, 2019].

Kerr, P.A. (2010). Conceptions and practice of information literacy in academic libraries: espoused theories and theories-in-use. [ $\mathrm{PhD}$ thesis]. Graduate School of New Brunswick: New Jersey.

Kreitz, P. A. (2015). Redefining the twenty-first century college library: Change leadership in academic libraries (Doctoral dissertation). Retrieved from PQDT Open https://pqdtopen.proquest.com/doc/17089 85779.html?FM. [accessed April 18, 2019].

Ludwig, L. \& Starr, S. (2005). Library as place: results of a Delphi study. Journal of Medical Library Association. 93(3). 315-326.

Lynch, R. (2006). Cooperate strategy. Prentice-Hall: London.

Malenfant, K. J. (2011). Understanding faculty perceptions of the future: an action research for academic librarians (Doctoral dissertation). Retrieved from http://aura.antioch.edu/etds/19. [accessed February 23, 2019].

Maness, J. (2006). Library 2.0 Theory: Web 2.0 and its implications for libraries. Webology, 3(2). Available at http://www.webology.org/2006/ v3n2 /a25.html. 
Moussetis, R. (2011). Ansoff revisited: how Ansoff interfaces with both the planning and learning schools of thought in strategy. Journal of Management History, 17(1), 102-125: DOI 10.1108/1751134 1111099556.

Musembe, C.N. (2016). Records management in institutions of higher learning: towards the business support function. International Journal of Library and Information Science Studies, 2(1), 13-28.

Neal, J.G. (2011).Stop the madness: the insanity of ROI and the need for new qualitative measures of academic library success. In Proceedings of the 2011 ACRL Conference, 424-439. Available at: www.ala.org/ acrl /files/conferences/confsandpreconfs/national/2011/ papers.

Punchihewa, C.N.D. (2018). How do Sri Lankan University libraries employ Web 2.0 tools in providing web-based library services? : a comparative study . Journal of the University Librarians Association of Sri Lanka, 21(1), 10-39. DOI:http://doi.org/10.4038/jula.v21i1.7909

Quanlan, N. \& Hegarty, N. (2006), Librarians outside the box: Waterford Institute of Technology's library-based virtual learning environment (VLE) training and development programme. New Library World 107(1/2), 37-47. DOI: $10.1108 / 03074800610639021$.

Ranaweera, A., \& Li, S. (2016). Web based library services of university libraries in Sri Lanka: A content analysis. In Proceedings of $8^{\text {th }}$ Shanghai International Library Forum (SILF2016). Shanghai, China

Rehman, A. \& Shafique, F. (2011). Use of Web 2.0 and its implications for libraries: Perceptions of Information Professionals in Pakistan. Library Philosophy and Practice [e-journal]. 623. Available at https://digitalcommons.unl.edu/libphilprac/623 [accessed October 23, 2019].

Sauers, M. \& Trueman, R. (2007). Second Life \& Info Island: library service in a Virtual World. [ppt presentation] available at https://www. slideshare.net/travelinlibrarian/second-life-info-island-library-service-in-avirtual-world.

Schilling, M. A. \& Hill, C.W. (1998), Managing the new product development process: strategic imperatives, Academy of Management Executive, 12(3), 67-81. 
Shafique, F. \& Riedling, A. (2013), Survival avenues for Pakistani libraries in the era of emerging technologies. The Electronic Library archive, 31(4), 412132, doi. 10.1108/EL-02-2011-0025.

Tait, E., Konstantina, M., \& Peter, R. (2016). Libraries for the future: the role of IT utilities in the transformation of academic libraries. Palgrave Communications, 2(1), 60-70. DOI:10.1057/palcomms.2016.70.

Tapera, J. (2014). The importance of strategic management to business organizations. The international Journal's (RJSSM), 3(11), 122-131.

Trtikova, I. \& Nemeckova, L. (2012). Marketing tools to support university library's mission. Qualitative and Quantitative Methods in Libraries (QQML), $1(2), 205-212$.

Virgil C.L. (2013). An analysis of the academic library and the changing role of the academic librarian in higher education: 1975 - 2012. [PhD. thesis]. Lindenwood University. Available at: https://pqdtopen.proquest.com/ doc/ 1466301072. html?FMT=AI.

Walton, G. (2007). Theory, research and practice in library management 3. Diversification, Library Management 28(6/7), 428-436.

Williams, D.E. \& Golden, J. (ed.s) (2011). Advances in library administration and organization. Vol 30. Emerald Group Publishing limited: Bingley. https://doi.org/10.1108/S0732-0671(2011)0000030012.

Wilson, K., Neylon, C., Montgomery, L., \& Huang, C.-K. (2019). Access to academic libraries: an indicator of openness? Information Research, 24(1), paper 809. Available at http://InformationR.net/ir/24-1/paper809.html (Archived by WebCite at http://www.webcitation.org/76tOSpfrn).

Xu, C., Ouyang, F. and Chu, H. (2009), The academic library meets Web 2.0: applications and implications. The Journal of Academic Librarianship, 35(4), 324-331, doi: 10.1016/j.acalib.2009.04.003.

Zhao, H. \& Luo, Y. (2002). Product diversification, ownership structure, and subsidiary performance in China's dynamic market. Management International Review (MIR), 42(1), 27-48. 